\title{
Exploring the Potential of Oil Palm (Elaeisguineensis), Spoilage, Before and During Harvest, in Nigeria
}

\author{
Prince Awojoodu Soji \\ Department of Computer Science and Mathematics, Oduduwa University, Ile-Ife Kingdom, Nigeria \\ Email address: \\ awojoodusoji@yahoo.com

\section{To cite this article:} \\ Prince Awojoodu Soji. Exploring the Potential of Oil Palm (Elaeisguineensis), Spoilage, Before and During Harvest, in Nigeria. American \\ Journal of Plant Biology. Vol. 4, No. 4, 2019, pp. 67-75. doi: 10.11648/j.ajpb.20190404.13
}

Received: September 11, 2019; Accepted: October 4, 2019; Published: October 17, 2019

\begin{abstract}
This research work, was carried out, to explore the potential of oil palm, spoilage, before and during harvest, in Nigeria. 3,600 open questionnaires were distributed to the 4 Local Governments, namely: (Ife East, Ife South, Ife Central and Ife North), local government areas in, Nigeria. Out of which 900 was used for farmers, in each local government. A total of 36 locations, were sampled in all the four local governments, out of which 100 questionnaires were used in each location. It was gathered that above $70 \%$ of the farmers supported, exploring the potential of oil palm (elaeisguineensis), spoilage, before and during harvest, in Nigeria, while less than $30 \%$ of the people could not even understand whether there was any needy, to explore the potential of oil palm (elaeisguineensis), spoilage, before and during harvest, in Nigeria, or not. The results from the questionnaires when using Pearson one-tailed correlation coefficient, however revealed that there was no significant difference from all the farmers visited and sampled, $(\mathrm{p}<0.05)$ table 5. This shows a strong positive correlation, which implying that, exploring the potential of oil palm (elaeisguineensis), spoilage, before and during harvest, in Nigeria, was strongly influenced and enhanced farmer's support, and had therefore, made this research work to become a reality, $(p<0.05)$ table 5 . The reasons may be due to the fact that in Nigeria, every part of palm oil is not only useful economically, for domestic purposes; the kernel cake gotten from kernel, when processed, can be used as a feed, for dairy cattle because of its high-protein content. It can also be used as a clearing agent, in baked goods, cosmetics, confectionery, shampoo, toothpaste, and washing detergents etc. Pie Chart was used to depict the summary data of each of the local government areas sampled.
\end{abstract}

Keywords: Oil Palm (ElaeisGuineensis), 4 Local Governments, Pearson One-Tailed Correlation, Spoilage, Harvest

\section{Introduction}

The oil palm tree belongs to the family of "Arecaceae" and genus "Elaeis". It has a botanical name of Elaeisguineensis, [1]. Oil palm is a perennial crop which grows in abundance in tropical areas; it bears a fruit known as palm fruit, which is the fleshy parts of the fruits covering the kennel. It has numerous benefits, as almost all the parts can be used in various applications, but its cultivation takes quite a lot of hard-work, dedication, and resources. Oil palms grow well in tropical areas like Nigeria, with so many oil palm plantations, but can still grow where there is an abundance of heat and rainfall. The oil palm is one of the highest oil (palm oil) yielding crops among the all perennial crops. Oil palm tree produces edible palm oil as well as palm kennel-oil. This oil palm is considered as golden palm, due its high yielding capacity. Every part of palm oil is useful economically, and for domestic purposes.

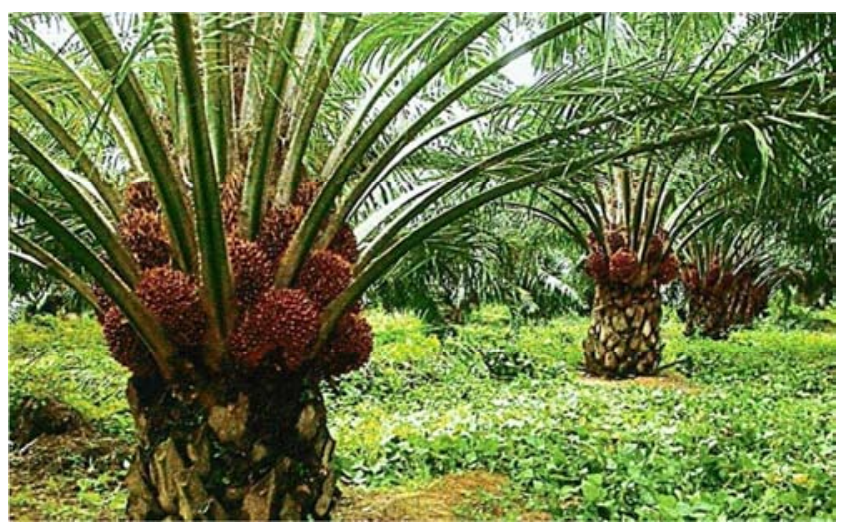

Figure 1. Every part of palm oil is useful economically, and for domestic purposes. 
The palm fruit, contains oil, which is processed when ripe into palm oil (edible vegetable oil), and the chaff (the palm fruit flesh), used to sustain fire; the kennel, is also processed into palm kernel oil, which is also addible and can be used for different applications, like: in making of soap, especially, bar soaps used in washing locally in Nigeria and some African countries. The kernel cake gotten from kernel. When processed, it is used as a feed, for dairy cattle because of its high-protein content. The kernel cake can also be used to generate electricity by burning it in boiler. Processing oil palm fruits for edible oil had been practiced in African for thousands of years, and the oil produced highly coloured and flavoured Also it is an essential ingredient in most of the traditional West African cuisine, [2]. The traditional process is very simple, but tedious and inefficient. Mature palms oil are in single streamed, and grow to $20 \mathrm{~m}$ tall. The leaves are primate, and reach between $3-5 \mathrm{~m}$ long. In Nigeria, it is cultivated in the South East Zone, and the Niger Delta areas. Oil palm products have numerous uses. It can be used as a clearing agent, in baked goods, cosmetics, confectionery, shampoo, toothpaste, and washing detergents. Oil palm generally can be used for different applications and is highly lucrative. Oil palm is a humid tropical crop and thrives best in the areas where temperature ranges from $22^{\circ} \mathrm{C}$ to $24^{\circ} \mathrm{C}$ (minimum) and $20^{\circ} \mathrm{C}$ to $33^{\circ} \mathrm{C}$ (maximum). Oil palms requires at least 5 to 6 hours of bright sunshine per day and $80 \%$ of humidity for optimum growth. This crop requires annual evenly distributed rainfall of 2500 to $4000 \mathrm{~mm}$ or 150 to $150 \mathrm{~mm}$ monthly, [3]. Generally, oil palms can be growth on wide range of soils. However, they thrives best in welldrained deep loamy moist and alluvial soil rich in organic matter. These trees require at least 1 meter of soil depth. Farmers should avoid highly saline, highly alkaline, coastal sandy and water stagnation soil. In Nigeria, the major oil palm producing states include: Enugu, Imo, Ondo, Edo, Cross River, Delta, Akwalbom, Ekiti, Bayelsa, Rivers, Anambra, Oyo, Abia, Edo, Osun, and Ogun State.

\subsection{Oil Palm History/Origin}

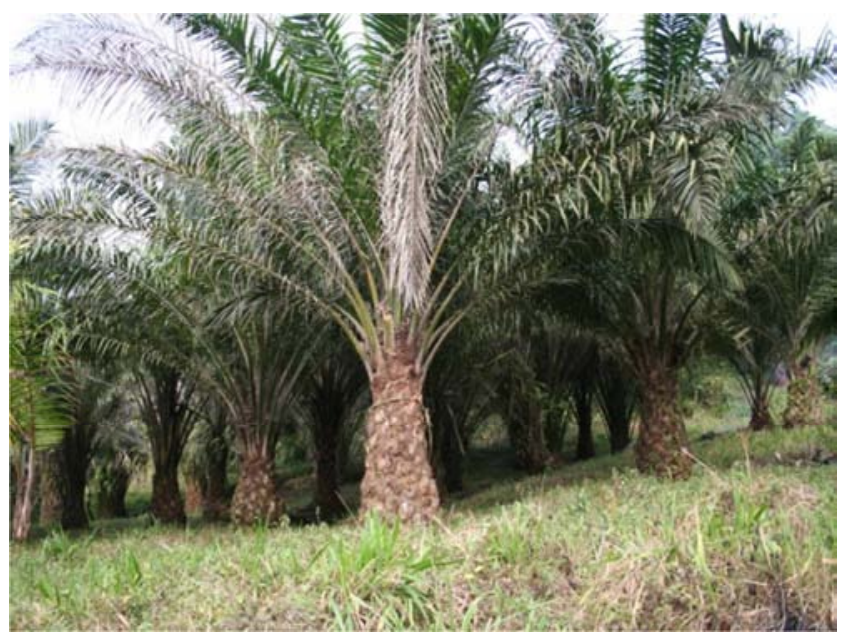

Figure 2. Currently, Nigeria palm oilproduction accounts for $7 \%$ of total global output.
Oil palm cultivation is originally from West Africa, which is located in a tropical areas, but currently grown throughout Africa, Asia, North America, and South America. Currently, Nigeria palm oil production accounts for $7 \%$ of total global output, [4]. It was generally agreed that the oil palm originated in the tropical rain forest region of West Africa. The main belt run through the southern latitudes of Cameroon, Cote'ivore, Ghana, Liberia, Nigeria, Sierraleone, Togo and into the equatorial region of Angola and the Congo.

\subsection{Years of Maturity of Oil Palm (Elaeisguineensis), in Nigeria}

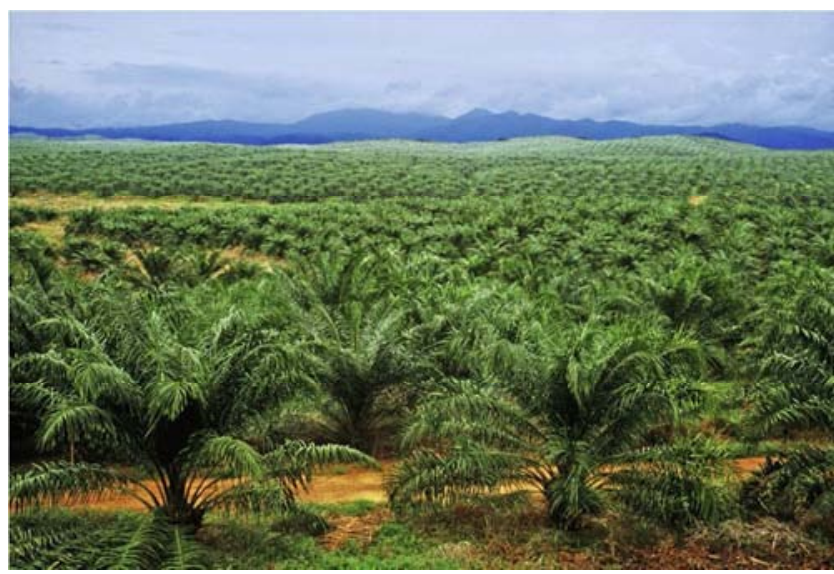

Figure 3. Oil Palm years of maturity.

After planting the oil palm, it takes 2 to 4 years before it grows to maturity, which literally means that, one may have to wait for that long, without gaining anything in reward. Irrespective of one time, and resources, which range from clearing of farmland, paying labourers, purchasing of fertilizers, seedling and more, but it is very rewarding at the end. The growing point of the adult oil palm produces 20 to 25 leaves, because, If there are many leaves, there will be many flowers. And if there are many flowers, there will be many clusters of fruit. The oil palm grows well and produces a lot in regions where it is very hot, where the sun is very strong, and where it rains a great deal. FLOWERING AND ABLATION: Oil palm trees start flowering in 14 to 18 months, after planting the crop. Oil palm tree produces both male and female flowers separately on the same palm tree. The process of removing male and female flowers in early stages of oil plantation is called ABLATION. Ablation is required in oil palm cultivation for development of stem girth, vigour and string root stem. Flowers should be removed manually or with recommended tools as soon as inflorescences appear on the oil palm tree. This process can be extended up2 or 3 years, depending on the tree vigour and growth. POLLINATION: The oil palm is a highly cross-pollinated crop, in which the insects and wind assist pollination. However, wind pollination is not sufficient and the insects like (Elaeidobilis Kamrunicus), assists in good fruit set and effective pollination, [5]. This weevil should be released after two and half years of planting and in case of low vigour and girth plantation, releasing the weevils after three years is advisable. 


\subsection{Oil Palm (Elaeisguineensis), Spoilage, Before and During Harvest, in Nigeria}
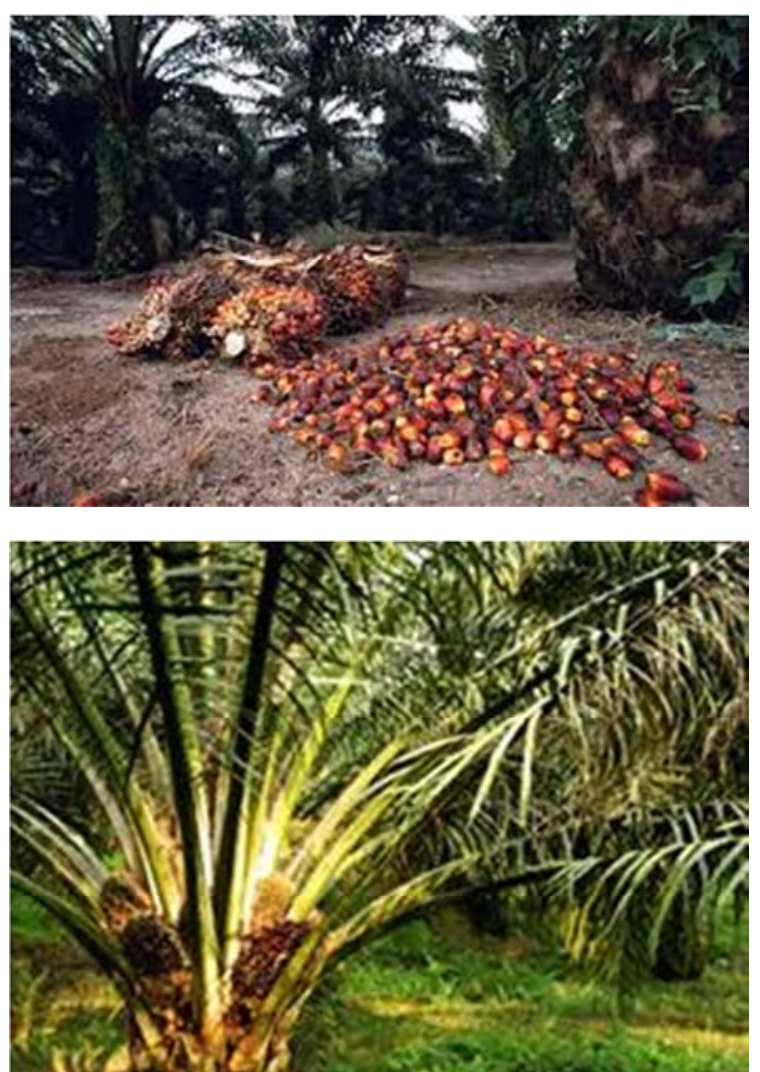

Figure 4. Oil Palm (Elaeis Guineensis), spoilage, before and during harvest.
Harvesting needs much care, because, only those fruit clusters which are cut at the right moment yield a lot of good quantity oil. A cluster is ripe for harvesting when the fruits begin to turn red, and when 5 or 6 fruits drop to the ground. The clusters of the oil palm consists of spikelet's. The spikelet's contain the fruit. Before getting the oil out of the fruit, the fruit must be separated from the spikelet's. The fruits of the oil palm consist of the following parts: PULP: the pulp is yellow; when the pulp is crushed, it yields palm oil. SEED: Inside the shell of the seed, is the kernel; when the kernel is crushed, it yields palm kernel oil. The kernel also contains the germ. Tools such as clausal, machetes, and sickle are used for the harvest, depending on the age of the plant. The major PEST OF OIL PALM includes: Rhinoceros beetle, Red palm weevil, mealy bug, nettle caterpillar, aphids, and termites etc. Others pest include: soil nematodes (e.g. Aphelenchusavenae, Helicotylenchus, spp., Meloidogyne spp.), which damage roots; and rodents, which can eat seedlings andfruits. OIL PALM DIESES includes: Blasts, Freckle (cercosporaelaeidis), Anthracnose, seedling Bright (curvulariaeragrostidis), Yellow Patch and Vascular Wilt (Fusariumoxysporum), Basal Trunk Rot; Crown disease and fruit Rot (marasmiuspalmivorus). Spear (bud) Rot, is caused by the bacterium Erwinia spp., which has been devastating in central Africa, [6].

\section{Material and Methods}

The responses of the people in different locations of the four local government areas can be seen from the decision table as below:

Table 1. The Decision Table.

\begin{tabular}{|c|c|c|c|}
\hline Sub & Above $70 \%$ & Below 30\% & Open headed Questionnaires \\
\hline $\begin{array}{l}\text { Exploring the potential of oil palm (elaeisguineensis), spoilage, before and during } \\
\text { harvest, in Nigeria. }\end{array}$ & $\mathrm{X}$ & & \\
\hline I do not know & & $\mathrm{X}$ & \\
\hline State open questionnaires & & & $\mathrm{X}$ \\
\hline
\end{tabular}

\subsection{Oil Palm (Elaeisguineensis) Points Ticked by 70\%, of the Farmers}

The below are the points ticked by the majority of the people (above $70 \%$ table 1), from the questionnaires who understood and supported, exploring the potential of oil palm (elaeisguineensis), spoilage, before and during harvest, in Nigeria:

\subsection{Oil Palm (Elaeisguineensis) Importance}

[a]. Palm oil is used for preventing vitamin A deficiency [b]. Palm oil can be used to produce biodiesel, which is also known as palm oil methyl Ester. [c]. It is used to treat people who have brain diseases, and ageing. [d]. Palm oil is also used to treat malaria, and high blood pressure [e]. Palm oil is used for weight loss, and increasing the body metabolism. [f]. It is used to treat high cholesterol and cyanide poisoning. [g]. As food, palm oil is used for cooking and frying. [h]. Industrially, palm oil is used for manufacturing cosmetics and soaps, [i]. It can also be used for manufacturing tooth paste and waxes. [j]. Palm oil is good and serve as a relief for cancer sufferer. [k]. Palm oil can be used for manufacturing lubricants and ink.[1]. Production of palm oil, is more sustainable than other vegetable oil. [m]. Palm oil consumes considerably, less energy in production.[n]. Palm oil production, uses less land, and generates more oil per hectare, than other leading vegetable oils-rapeseed.. [o]. Farmers can expect high returns which results in uplift of economic status.[p]. In Nigeria, palm oil crop assures monthly income and good market price throughout the year.[q]. Oil palm is a hardy crop and low pest and disease incidence.[r]. Palm oil yields highest edible oil among the other oil crops. The yield of 4 to 5 tonnes/ha can be expected. [s]. Farmers can get extra income by intercropping in pre-bearing period of oil palms. [t]. There is no risk of theft, and it also provides local employment. 


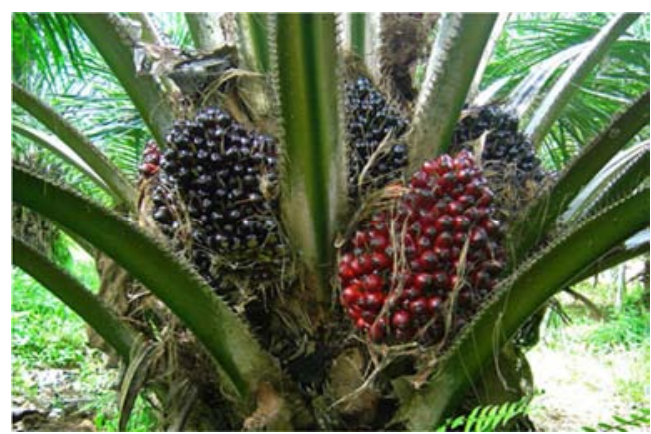

Figure 5. The potential of oil palm (elaeisguineensis), spoilage, before and during harvest, in Nigeria.

\section{Study Area}

The study has been conducted in Nigeria. It is located in the West of Africa on the Gulf of guinea and has a total of 923,768 $\mathrm{km}^{2}$ (356.669 square mile), making it the world's $32^{\text {nd }}$-largest country (after Tanzania). It is comparable in size to Venezuela, and is about twice the size of California. It shares a 4.047 kilometers (2.515 square mile), border with Benin (773 km.), Niger (1497 km.), Chad (87 km.), Cameroon (1690 km.), and has a coastline of at least $853 \mathrm{~km}$. [51]. Nigeria lies between latitude $4^{\circ}$ and $14^{\circ} \mathrm{N}$, and longitude $2^{\circ}$ and $15^{\circ} \mathrm{E}$ (Encyclopedia Britannica). Nigeria is a densely populated country with the highest density of 477.0/square mile. As at a (2012) estimate, the country held a population of more than 168.8 million people up from the 140 million recorded in her (2006) population census (World Bank Nigeria Data (2012)). Of this population, about 87 million people (52\%) dwell in rural areas while 81 million dwell in urban areas (Trading Economics Rural Population Chart (2012). The Male/Female ratio is 1:05, where male commands $51.21 \%$, while females, $48.79 \%$ (Nigerian Census, (2006)).

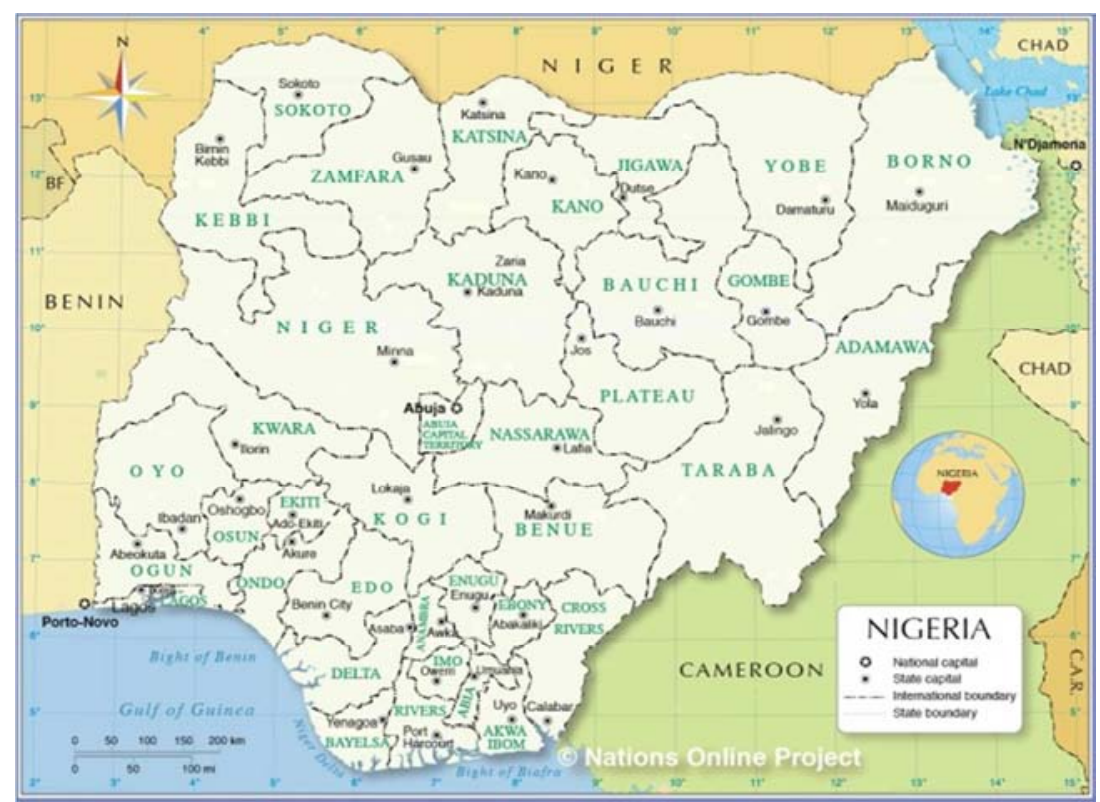

Figure 6. The study area map of Nigeria.

\section{Results and Discussion}

Questionnaires were distributed to 4 Local government areas that is, (Ife East, Ife South, Ife Central and Ife North). The results from the questionnaires however revealed that, exploring the potential of oil palm (elaeisguineensis), spoilage, before andduring harvest, in Nigeria, are manifold:

There was no significant difference on the people in all the local government areas visited, $(\mathrm{p}<0.01)$.

Table 2. People's response.

\begin{tabular}{|c|c|c|c|c|c|c|c|c|}
\hline Wards & Ife East & & Ife South & & Ife Central & & Ife North & \\
\hline $\begin{array}{l}\text { People's } \\
\text { Response }\end{array}$ & $\begin{array}{l}\text { Exploring the } \\
\text { potentialof oil palm } \\
\text { (elaeisguineensis), } \\
\text { spoilage, before and } \\
\text { during harvest, } \\
\text { inNigeria. }\end{array}$ & $\begin{array}{l}\text { I do not } \\
\text { know }\end{array}$ & $\begin{array}{l}\text { Exploring the } \\
\text { potentialof oil palm } \\
\text { (elaeisguineensis), } \\
\text { spoilage, before and } \\
\text { during harvest, } \\
\text { inNigeria. }\end{array}$ & $\begin{array}{l}\text { I do not } \\
\text { know }\end{array}$ & $\begin{array}{l}\text { Exploring the } \\
\text { potentialof oil } \\
\text { palm } \\
\text { (elaeisguineensis), } \\
\text { spoilage, before } \\
\text { and during } \\
\text { harvest, inNigeria. }\end{array}$ & $\begin{array}{l}\text { I do not } \\
\text { know }\end{array}$ & $\begin{array}{l}\text { Exploring the } \\
\text { potentialof oil } \\
\text { palm } \\
\text { (elaeisguineensis), } \\
\text { spoilage, before } \\
\text { and during harvest, } \\
\text { inNigeria. }\end{array}$ & $\begin{array}{l}\text { I do not } \\
\text { know }\end{array}$ \\
\hline
\end{tabular}

From the above table2, in Ife East, there are624 people's response with $69.3 \%$, Ife South, 636 with $70.7 \%$, Ife Central,
633 with $70.3 \%$, and Ife North, 629 with $69.9 \%$, were those People who supported, exploring the potential of oil palm 
(elaeisguineensis), spoilage, before and during harvest, in Nigeria.; while in Ife East, 276 with 30.7\%, Ife South, 264 with $29.3 \%$, Ife Central, 267 with $29.7 \%$, andIfe North, 271 with $30.1 \%$ respectively, could not even know whether to explore the potential of oil palm (elaeisguineensis), spoilage, before and during harvest, in Nigeria, or not.

Table 3. The different locations as (A, B, C, D, E, F, G, Hand I) and thelocal government areas as (IFE EAST, IFE SOUTH, IFECENTRAL, AND IFE NORTH respectively). Also the summary data collected, from the 4 Local Governments sampled, out of which 900 were used in each local government.

\begin{tabular}{|c|c|c|c|c|c|c|c|c|c|}
\hline \multirow[t]{2}{*}{ LOCAL GOVERNMENT } & \multirow{2}{*}{$\begin{array}{l}\text { LOCATION } \\
\text { A }\end{array}$} & \multicolumn{2}{|c|}{ IFE EAST } & \multicolumn{2}{|c|}{ IFE SOUTH } & \multicolumn{2}{|c|}{ IFE CENTRAL } & \multicolumn{2}{|c|}{ IFE NORTH } \\
\hline & & 71 & 29 & 68 & 32 & 75 & 25 & 68 & 32 \\
\hline \multirow{7}{*}{ Peoples Respondent } & $\mathrm{B}$ & 72 & 28 & 72 & 28 & 73 & 27 & 79 & 21 \\
\hline & $\mathrm{C}$ & 63 & 37 & 70 & 30 & 69 & 31 & 70 & 30 \\
\hline & $\mathrm{D}$ & 63 & 37 & 64 & 36 & 64 & 36 & 63 & 37 \\
\hline & $\mathrm{E}$ & 64 & 36 & 76 & 24 & 75 & 25 & 72 & 28 \\
\hline & $\mathrm{F}$ & 69 & 31 & 79 & 21 & 78 & 22 & 74 & 26 \\
\hline & G & 74 & 26 & 70 & 30 & 68 & 32 & 67 & 33 \\
\hline & I & 72 & 28 & 65 & 35 & 67 & 33 & 68 & 32 \\
\hline TOTAL = & 9 & 624 & 276 & 636 & 264 & 633 & 267 & 629 & 271 \\
\hline Grand Total $=$ & 9 & 900 & & 900 & & 900 & & 900 & \\
\hline
\end{tabular}

Table 4. The descriptive statistics.

\begin{tabular}{llll}
\hline Descriptive Statistics & & & \\
\hline & Mean & Std. Deviation & N \\
\hline IFEEAST & 69.3333 & 4.89898 & 9 \\
IFESOUTH & 70.6667 & 4.82183 & 9 \\
IFECENTRAL & 70.3333 & 5.09902 & 9 \\
IFENORTH & 69.8889 & 4.62181 & 9 \\
\hline
\end{tabular}

Correlations

Table 5. ThePearson Correlationforthe 4 local governments.

\begin{tabular}{|c|c|c|c|c|c|}
\hline \multicolumn{6}{|l|}{ Correlations } \\
\hline & & IFEEAST & IFESOUTH & IFECENTRAL & IFENORTH \\
\hline \multirow{5}{*}{ IFEEAST } & Pearson Correlation & 1 & .026 & -.130 & .112 \\
\hline & Sig. (1-tailed) & & .473 & .369 & .387 \\
\hline & Sum of Squares and Cross-products & 192.000 & 5.000 & -26.000 & 20.333 \\
\hline & Covariance & 24.000 & .625 & -3.250 & 2.542 \\
\hline & $\mathrm{N}$ & 9 & 9 & 9 & 9 \\
\hline \multirow{4}{*}{ IFESOUTH } & Pearson Correlation & .026 & 1 & $.686^{*}$ & $.666^{*}$ \\
\hline & Sum of Squares and Cross-products & 5.000 & 186.000 & 135.000 & 118.667 \\
\hline & Covariance & .625 & 23.250 & 16.875 & 14.833 \\
\hline & $\mathrm{N}$ & 9 & 9 & 9 & 9 \\
\hline \multirow{4}{*}{ IFECENTRAL } & Pearson Correlation & -.130 & $.686^{*}$ & 1 & $.665^{*}$ \\
\hline & Sig. (1-tailed) & .369 & .021 & & .025 \\
\hline & Sum of Squares and Cross-products & -26.000 & 135.000 & 208.000 & 125.333 \\
\hline & Covariance & -3.250 & 16.875 & 26.000 & 15.667 \\
\hline \multirow{4}{*}{ IFENORTH } & Sig. (1-tailed) & .387 & .025 & .025 & \\
\hline & Sum of Squares and Cross-products & 20.333 & 118.667 & 125.333 & 170.889 \\
\hline & Covariance & 2.542 & 14.833 & 15.667 & 21.361 \\
\hline & $\mathrm{N}$ & 9 & 9 & 9 & 9 \\
\hline
\end{tabular}

*. Correlation is significant at the 0.05 level (1-tailed).

FREQUENCIES VARIABLES=IFEEAST IFESOUTH IFECENTRAL IFENORTH

/NTILES $=4$

NTILES $=10$

/STATISTICS=STDDEV VARIANCE RANGE MINIMUM MAXIMUM SEMEAN MEAN MEDIAN MODE SUM SKEWNESS SESKEW

KURTOSIS SEKURT

/GROUPED=IFEEAST IFESOUTH IFECENTRAL IFENORTH

/ORDER=ANALYSIS. 
Table 6. Themean, mode, std. deviation of the 4 local government areas.

\begin{tabular}{|c|c|c|c|c|c|}
\hline \multicolumn{6}{|l|}{ Statistics } \\
\hline & & IFEEAST & IFESOUTH & IFECENTRAL & IFENORTH \\
\hline \multirow{2}{*}{$\mathrm{N}$} & Valid & 9 & 9 & 9 & 9 \\
\hline & Missing & 0 & 0 & 0 & 0 \\
\hline \multicolumn{2}{|l|}{ Mean } & 69.3333 & 70.6667 & 70.3333 & 69.8889 \\
\hline \multicolumn{2}{|c|}{ Std. Error of Mean } & 1.63299 & 1.60728 & 1.69967 & 1.54060 \\
\hline \multicolumn{2}{|c|}{ Median } & $71.0000^{\mathrm{a}}$ & $70.5000^{\mathrm{a}}$ & $69.0000^{\mathrm{a}}$ & $69.0000^{\mathrm{a}}$ \\
\hline \multicolumn{2}{|l|}{ Mode } & $63.00^{\mathrm{b}}$ & $70.00^{\mathrm{b}}$ & $64.00^{\mathrm{b}}$ & 68.00 \\
\hline \multicolumn{2}{|c|}{ Std. Deviation } & 4.89898 & 4.82183 & 5.09902 & 4.62181 \\
\hline \multicolumn{2}{|c|}{ Variance } & 24.000 & 23.250 & 26.000 & 21.361 \\
\hline \multicolumn{2}{|l|}{ Skewness } & -.300 & .340 & .137 & .755 \\
\hline \multicolumn{2}{|c|}{ Std. Error of Skewness } & .717 & .717 & .717 & .717 \\
\hline \multicolumn{2}{|c|}{ Kurtosis } & -1.509 & -.263 & -1.470 & 1.038 \\
\hline \multicolumn{2}{|c|}{ Std. Error of Kurtosis } & 1.400 & 1.400 & 1.400 & 1.400 \\
\hline \multicolumn{2}{|c|}{ Range } & 13.00 & 15.00 & 14.00 & 16.00 \\
\hline \multicolumn{2}{|l|}{ Minimum } & 63.00 & 64.00 & 64.00 & 63.00 \\
\hline \multicolumn{2}{|l|}{ Maximum } & 76.00 & 79.00 & 78.00 & 79.00 \\
\hline \multirow{2}{*}{\multicolumn{2}{|c|}{ Sum }} & 624.00 & 636.00 & 633.00 & 629.00 \\
\hline & 10 & $. c, d$ & $64.4000^{\mathrm{d}}$ & $c, d$ & $64.6000^{\mathrm{d}}$ \\
\hline \multirow{10}{*}{ Percentiles } & 20 & 63.5333 & 65.9000 & 65.6000 & 67.1500 \\
\hline & 25 & 63.8333 & 67.2500 & 66.5000 & 67.3750 \\
\hline & 30 & 65.0000 & 68.2667 & 67.2000 & 67.6000 \\
\hline & 40 & 69.2000 & 69.4667 & 68.1000 & 68.1000 \\
\hline & 50 & 71.0000 & 70.5000 & 69.0000 & 69.0000 \\
\hline & 60 & 71.6000 & 71.4000 & 72.6000 & 69.9000 \\
\hline & 70 & 72.4000 & 72.8000 & 74.0667 & 71.6000 \\
\hline & 75 & 73.0000 & 74.0000 & 74.6667 & 72.5000 \\
\hline & 80 & 73.6000 & 75.2000 & 75.4000 & 73.4000 \\
\hline & 90 & 75.2000 & 77.8000 & 77.2000 & 77.0000 \\
\hline
\end{tabular}

a. Calculated from grouped data.

b. Multiple modes exist. The smallest value is shown

c. The lower bound of the first interval or the upper bound of the last interval is not known. Some percentiles are undefined.

d. Percentiles are calculated from grouped data.

Frequency Table

Tables (7, 8, 9, and 10). The frequency Tables for (Ife East, Ife South, Ife Central andIfe North).

Table 7. Validand cumulative percentagesofIfe East.

\begin{tabular}{llllll}
\hline IFEEAST & & & & \\
\hline & & Frequency & Percent & Valid Percent & Cumulative Percent \\
\hline \multirow{4}{*}{ Valid } & 63.00 & 2 & 22.2 & 22.2 & 22.2 \\
& 64.00 & 1 & 11.1 & 11.1 & 33.3 \\
& 69.00 & 1 & 11.1 & 11.1 & 44.4 \\
& 71.00 & 1 & 11.1 & 11.1 & 55.6 \\
\\
& 72.00 & 2 & 22.2 & 11.1 & 77.8 \\
\\
& 74.00 & 1 & 11.1 & 11.1 & 100.0 \\
\end{tabular}

Table 8. Validand cumulative percentages of Ife South.

\begin{tabular}{llllll}
\hline IFESOUTH & & & & & \\
\hline & & Frequency & Percent & Valid Percent & Cumulative Percent \\
\hline & 64.00 & 1 & 11.1 & 11.1 & 11.1 \\
Valid & 65.00 & 1 & 11.1 & 11.1 & 22.2 \\
& 68.00 & 1 & 11.1 & 11.1 & 33.3 \\
& 70.00 & 2 & 22.2 & 22.2 & 55.6 \\
\\
& 72.00 & 2 & 22.2 & 11.1 & 87.8 \\
\\
& 76.00 & 1 & 11.1 & 11.1 & 100.0 \\
\hline
\end{tabular}


Table 9. Validand cumulative percentages of Ife Central.

\begin{tabular}{|c|c|c|c|c|c|}
\hline \multicolumn{6}{|c|}{ IFECENTRAL } \\
\hline & & Frequency & Percent & Valid Percent & Cumulative Percent \\
\hline \multirow{8}{*}{ Valid } & 64.00 & 2 & 22.2 & 22.2 & 22.2 \\
\hline & 67.00 & 1 & 11.1 & 11.1 & 33.3 \\
\hline & 68.00 & 1 & 11.1 & 11.1 & 44.4 \\
\hline & 69.00 & 1 & 11.1 & 11.1 & 55.6 \\
\hline & 73.00 & 1 & 11.1 & 11.1 & 66.7 \\
\hline & 75.00 & 2 & 22.2 & 22.2 & 88.9 \\
\hline & 78.00 & 1 & 11.1 & 11.1 & 100.0 \\
\hline & Total & 9 & 100.0 & 100.0 & \\
\hline
\end{tabular}

Table 10. Validand cumulative percentages of Ife North.

\begin{tabular}{|c|c|c|c|c|c|}
\hline \multicolumn{6}{|c|}{ IFENORTH } \\
\hline & & Frequency & Percent & Valid Percent & Cumulative Percent \\
\hline \multirow{8}{*}{ Valid } & 63.00 & 1 & 11.1 & 11.1 & 11.1 \\
\hline & 67.00 & 1 & 11.1 & 11.1 & 22.2 \\
\hline & 68.00 & 3 & 33.3 & 33.3 & 55.6 \\
\hline & 70.00 & 1 & 11.1 & 11.1 & 66.7 \\
\hline & 72.00 & 1 & 11.1 & 11.1 & 77.8 \\
\hline & 74.00 & 1 & 11.1 & 11.1 & 88.9 \\
\hline & 79.00 & 1 & 11.1 & 11.1 & 100.0 \\
\hline & Total & 9 & 100.0 & 100.0 & \\
\hline
\end{tabular}

Figures: (7, 8, 9, and 10). Pie Bar Charts, for (Ife East, Ife South, Ife Central andIfe North)

PIEChart
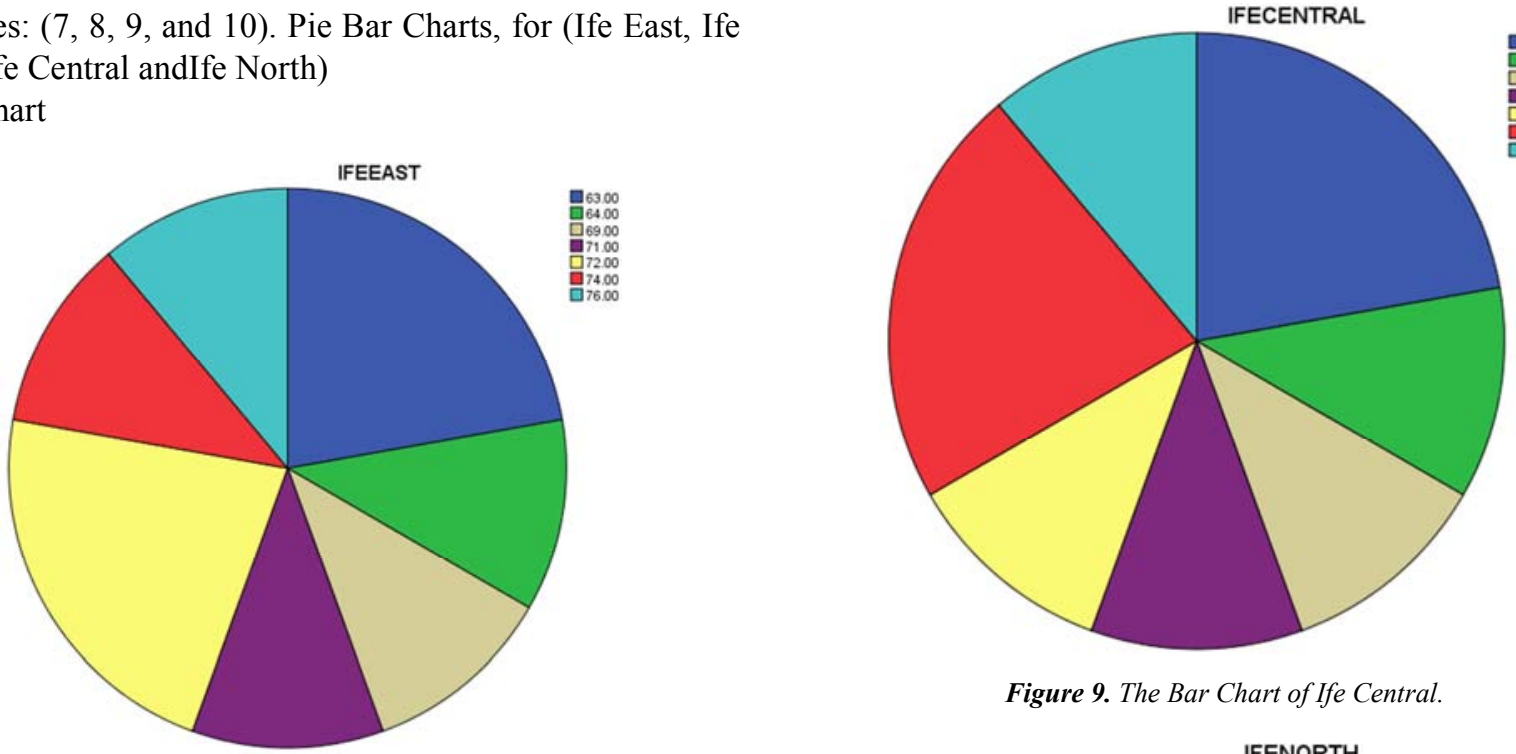

Figure 9. The Bar Chart of Ife Central.

Figure 7. The Bar Chart of Ife East.

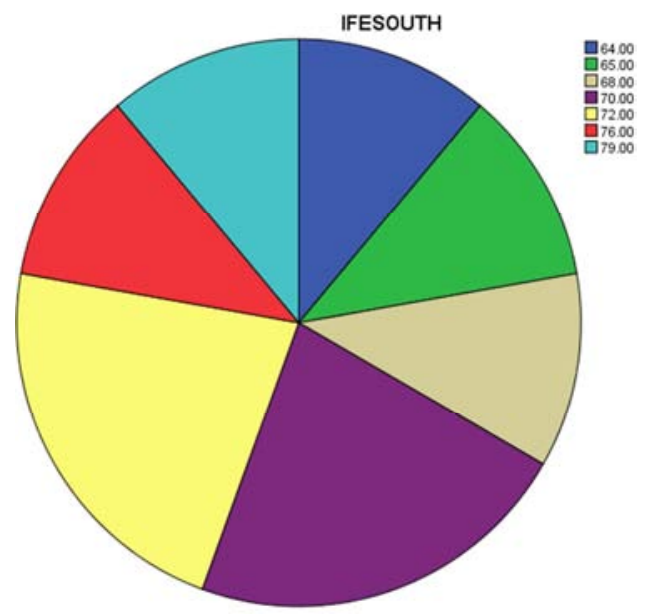

Figure 8. The Bar Chart of Ife South.

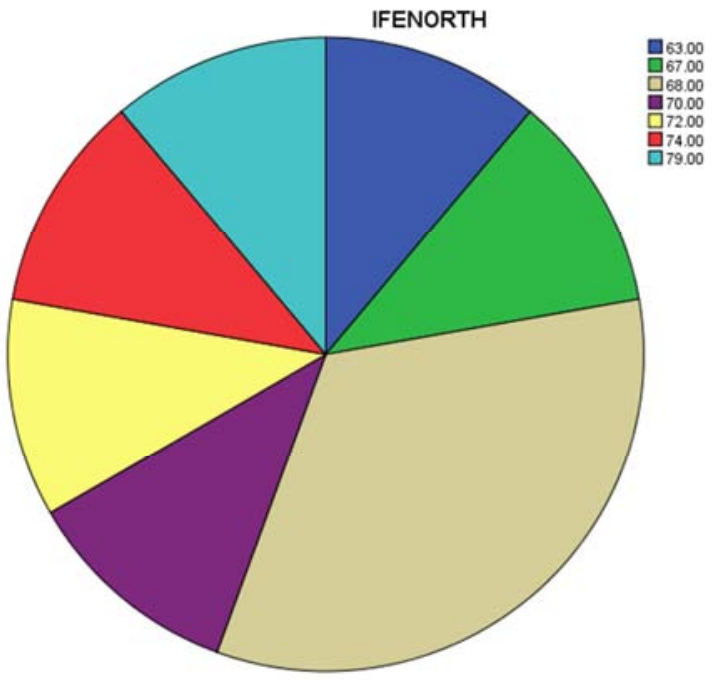

Figure 10. The Bar Chart of Ife North. 


\section{Recommendations}

1. Workshop at different intervals should be organized to farmers, so as to educate them in the uses of current farmer's equipments, to increase their oil palm output production and eradicate plantain spoilage.

2. Nigerian Government should encourage oil palm plantation, by given funds/loans to prospective investors

3. Government should provide electricity in rural areas for Farmers to enable them to stay longer in their farm for maximum increase in their oil palm harvest Production.

4. Federal government should support the farmers by given enough assistance in terms of seedlings subsidy, so as to booth their production

5. Government should organized Agricultural extension services to farmers by providing and bringing agricultural equipments closer to them, so as to reduce the cost of oil palm harvest to the buyers.

6. For high Productivity and ultimate high investment, the Federal Government of Nigeria should encouraged oil palm farmers to make research and seek expert opinion and advice for the latest productivity techniques to maximize profit.

7. Government should erect large storage facilities at intervals for oil palm farmers, to avoid losses and spoilage.

8. Some of the rural areas roads in, Nigeria, are bad. Government should provide good motor-able roads to farmers in oil palm areas with high concentration of oil palm farm.

\section{Conclusion}

The following conclusions are made based on the findings of this study. Since, oil palm products, can not only be used as a clearing agent, in baked goods, cosmetics, confectionery, shampoo, toothpaste, and washing detergents; the kennel derived from oil palm, when processed, into palm kernel oil, which is also addible, can be used for different applications, like: in making of soap, especially, bar soaps used in washing locally in Nigeria and some African countries. The kernel cake gotten from kernel, when processed also, is used as a feed, for dairy cattle because of its high-protein content; while the kernel cake, can also be used to generate electricity by burning it in boiler, etc.; the results of this study provide the empirical evidence that, exploring the potential of oil palm (elaeisguineensis), spoilage, before and during harvest, in Nigeria, had enhanced people's achievement in our society and in Nigeria at large. The society, therefore should use, exploring the potential of oil palm (elaeisguineensis), spoilage, before and during harvest, in Nigeria's techniques, to argument peoples' and farmers' maximal output in businesses, in order to attain minimum goal needed for everybody in the society in general, Nigeria and Diaspora, at large.

\section{Acknowledgements}

The Author wishes to express his appreciations to all especially those whose papers that are shown in my references to provide the premise for this study, and Dr. / Chief Ramond Adedoyin, (The ATOBATELE, and MAYE of the Yoruba Kingdom); The Chancellor and Founder of Oduduwa University for providing the fund and space to carry out this research work / study.

\section{References}

[1] Aderinlewo E. O., 1982. Basic Secondary Science Book 1. Published by Evans Brothers Limited. Montague House, Russell square London WC1B5BX. Composition in 11 on 13point century by Film type services Limited, Scarborough, North Yorkshire and Printed by William Clowes (Beccles) Limited, Beccles and London ISBN 0237505274 . NPR 1137.

[2] Ashutosh Kar, 2011. Advanced Practical Chemistry. First Edition. Printed in India at Saras Graphics, Rai, Haryana. Typeset at Goswami Associates, Delhi. Publishing for one world. New Age International (P) Limited, Publishers. 4835/24, Ansari Road, Daryaganj, New Delhi. ISBN (0): 81224-1539-9. ISBN (13): 978-81-224-1539-1.

[3] C. M. A. Ademoroti, 2016. Environmental Chemistry \& Toxicology. Printed and Printed by: Folex Press Ltd., Ibadan. Typing and Manuscript: Mareh Prints andConsultancy. 47, Jona Akpaborie Street, BDPA, Ugbowo Estate, Benin. ISBN: 978-32413-1-1.

[4] Dr. Tilak Ram, 2013. Food Chemistry. Published in India by Random Publications. 4376-A/4B. Gall Murari Lai, Ansari Road, New Delhi-110002. Typesetting by: Friends Media, Delhi. Digitally Printed at: Replica Press Pvt. Ltd. ISBN 97893-5111-032-3.

[5] Elservier, E. 2009. Guide to Protein Purification. $2^{\text {nd }}$ Edition. Academic Press. 525B street, suite 1900. San Diego, a 921014495, USA, 30 corporate Drive. Suite 400, Burlington, MA 01803, USA. 32 Jamestown Road, London. NW1 7BY, UK. ISBN. (hardback). ISBN: 978-0-12-374978-9 (paper back). ISSN: 0076-6879.

[6] Erelu, O. O., 2008. Cocoa for Health and Wealth. A Paper presented in a Fourth Cocoa Day Celebrationin Osun State between $22^{\text {nd }}-24^{\text {th }}$ April.

[7] Fan Y. Ding Z. Yang L. et al. A Preliminary Study on Bioactivity of Orange and Tangerine Pealextracts against Apulia and mites. Zhongguo Zhong Yao ZaZhi 1995 Jul: 20 (7): 397-8, 446. 1995. PMID: 13090.

[8] George Coulouris, Jean Dollimore and Tim Kindberg, 2011. Distributed Systems, Conceptsand Design, $4^{\text {th }}$ Edition. Published by Dorling Kindersley [India] Pvt. Ltd. Licensees of Pearson Education in South Asia. Head Office: $7^{\text {th }}$ floor, Knowledge Bouleward. A-8 [A]. India Registered Office: 11Community Centre, Panchsheel Park. New Delhi. India. Printed in India by Municipal Press Ltd. ISBN978-81-317-1840-7. Authorized adaptation from the United Kingdom Edition, Entitled Distributed System Concepts and Design. Forth Edition, ISBN: 9780321263544 by Koulouris, George: Doll more, Jean; Kind berg, Tim; Published by Education, Ltd. Indian Subcontinent Adaptation Dorling Kindersley [India] Pvt. Ltd. 
[9] Gordon M. Wardlaw, 2003. Contemporary Nutrition Issues and Insight. Fifth Edition. Published by McGraw-hill, a business unit of McGraw-Hill Companies, Inc., New York, NY 10020. ISBN: 0-07-286530-X. ISBN: 0-07-119903-X (15E). International Edition. ISBN: 0-07-118808-X.

[10] Honow R., Laube N. Schneider A, Kessier T. Hesser. Influence of grape fruit, Orange, and applejuice consumption on urinary variables and risk of crystallization. Br. Intr. Aug: 90 (2)295-300.2003. PMID: 12908889.

[11] Jill Norman, 1997. The Classic Herb Cook Book. First published in Great Britain by Dorling Kindersley Limited. 9, Henrietta Street, London WC2E8PS. Reprint in 1997. A CIP for this book is available from the British Library. ISBN: 0751303232. Reproduced in Italy by Scanner Service SRL. Printed and bound in Italy by a Monadori, Veronica.

[12] John R. Holum, 1975. Experiments in General Organic and Biological Chemistry. A laboratory Manual, Forth Edition. New York. London. Sydney. Toronto. Printed in the United Stateof America. 10987654321.

[13] Kumar R., 1984. Insect Pest Control. First Published in Great Britain. Printed and bound inGreat Britain by Athenaeum Press Ltd. Gates head British Library Cataloguing inPublication Data. ISBN 0713180838. Member of the Holder Headline Group. 338 Euston Road, London WW1 3BH.

[14] Melvin Calvin and J. A Bass ham 1962. The Photosynthesis of Carbon Compounds. Library of Congress Catalogue Card Number: 62-10567. Manufactured in the United States of America. The Manuscripts was received November 15, 1961, and Published February 27, 1962. W. A. Benjamin, Inc. 2465 Broadway, New York 25, New York.

[15] Nyle C. Brandy, 1990. The nature and Properties of Soils. Printed in the United State of America by Mac Millian Publishing Company. Simon \& Schuster A. Viacon Company, Upper Saddle River, New Jersey, 074p58. ISBN 0-13-852444-0.
[16] Oduduwa University, 2016. General Inorganic Chemistry. Press Publication Ltd. Egbeda/Idimu Road, Egbeda, Lagos. ISBN: 978-978-50449-5-9.

[17] Oluyole K. A., 2005. Evaluation of the Economic of Post Harvest Processing of Cocoa in Cross River State, Nigeria. Journal of Agriculture, Forestry and the Social Sciences.

[18] O. P. Agarwal, 2014. Organic Chemistry, Natural Products Volume-1. Published by: Satyendra Rostogi, "mitra" for KRISHNA Prakasha media (P) Ltd. 11, Shivaji Road, India. Printed at Majmoon Press, Meerut. Typing: DEBUG CC. (The computer concern) Ghaziabad, ISBN: 978-81-8283-556-6.

[19] Rai H., 2004. Basic Industrial Biochemistry. Printed in India at Ram Pictograph, Delhi. Typeset at In-house. Publishing for one world. New Age International (P) limited. Publishers. Daryaganj, New Delhi. ISBN: 978-81-224-3404-0.295. C-1204-6261.

[20] Rama Rao Nadendla, 2016. Principles of Organic Medicinal Chemistry. Published by New Age International (P) Ltd., Publishers. ISBN: 81-224-1571-7. Printed in India at Ajit Printers, Delhi. Printers, Delhi.

[21] Rapisarda P. Tomaino A. Lo Cascio R., et al. Antioxidant effectiveness as influenced by Phenolcontent of fresh orange juices. J, Agric Food Chem. 1999 Nov: 47 (11): 4718-23.1999. PMID: 13080.

[22] S. K. Jain, 2001. Mineral Processing. For CBS Publishers and Distributors Pvt. Ltd. CBSPlaza, Prahlad Street, Daryaganj, New Delhi- India. Ph: 23289259, 232668861, 23266867. ISBN: 81-239-0753-2.

[23] Tilak Wasan, 2015. Solid Waste Pollution and Health. Published at Arisari Road, 4383/4B, Darga Ganj. New Delhi110002 (India). ISBN: 978-93-5056-306-9. Discovery Publishing House PVT. Ltd. Printed at: Infinity Imaging Systems Delhi. 